\title{
ANALISIS IMPLEMENTASI KEBIJAKAN DALAM PENGELOLAAN KAWASAN PERBATASAN NEGARA DI PROVINSI KEPULAUAN RIAU
}

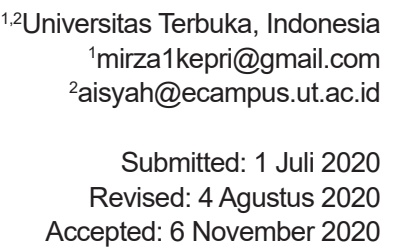

Submitted: 1 Juli 2020

Revised: 4 Agustus 2020 Accepted: 6 November 2020

\author{
Mirza $^{1}$ dan Siti Aisyah ${ }^{2}$
}

\begin{abstract}
This research aimed to anlayze the implementation of border management policies in Riau Islands Province, which at the provincial level, state border management policies were coordinated through government bureaus and borders. Research problems included the coordination of the implementation of state border development programs that have not yet been integrated, the weakness of institutional institutions that oversaw national border policies and the needs for commitment by state administrators to be carried out in the form of programs/activities in border areas. This study used a qualitative approach with descriptive methods. Data analysis was conducted based on George Edward III's Policy Implementation theory, covering aspects of communication, resources, disposition and bureaucratic structure. The conclusion of this study was that the implementation of sectoral coordination and ego was still a problem, including bureaucratic fragmentation with diffused subjects, making implementation of policies less directed and integrated. Strengthening the border issues became the development program in the Riau Islands Provincial Government to to improve the welfare of the people in the border areas. The program should be then included in the Regional Development Plan (RPJMD).
\end{abstract}

Keywords: Policy Implementation, Border Area, Riau Islands

\section{PENDAHULUAN}

Provinsi Kepulauan Riau lebih lima puluh persen wilayahnya ditetapkan oleh pemerintah pusat sebagai kawasan perbatasan negara. Penetapan ini seiring dengan keluarnya desain besar pengelolaan batas wilayah negara dan kawasan perbatasan 2011-2025 melalui peraturan Badan Nasional Pengelola Perbatasan (BNPP) No 1 tahun 2011 serta rencana induk BNPP yang memuat sasaran penangan lokasi prioritas kawasan perbatasan di Indonesia. Berdasarkan peraturan ini terdapat 41 kecamatan lokasi prioritas kawasan perbatasan di Kepulauan Riau. Di Provinsi Kepulauan Riau secara keseluruhan terdapat 70 kecamatan yang tersebar di 7 Kabupaten/Kota. Kawasan perbatasan menurut Undang-Undang RI Nomor 43 Tahun 2008 tentang wilayah negara adalah bagian dari Wilayah Negara yang terletak pada sisi dalam yang berada di kecamatan sepanjang batas wilayah Indonesia dengan negara lain.

Sementara itu istilah kawasan perbatasan menurut rencana induk pengelolaan perbatasan negara Badan Nasional Pengelola Perbatasan (BNPP) merupakan wilayah hukum Negara Kesatuan Republik Indonesia yang berbatasan dengan negara lain, dan batas-batas wilayahnya ditentukan berdasarkan peraturan perundangundangan yang berlaku. Undang Undang Nomor 26 Tahun 2007 tentang Penataan Ruang menggolongkan wilayah perbatasan menjadi kawasan strategis nasional yaitu sebagai wilayah 
yang penataan ruangnya diprioritaskan karena mempunyai pengaruh sangat penting secara nasional terhadap kedaulatan negara, pertahanan dan keamanan negara, ekonomi, sosial, budaya, dan lingkungan. Pengelolaan kawasan perbatasan diperlukan untuk memberikan kepastian hukum mengenai ruang lingkup wilayah negara, batas wilayah negara dan kewenangan pengelolaan wilayah negara, dan hak-hak berdaulat, serta dilakukan dengan pendekatan kesejahteraan, keamanan, dan kelestarian lingkungan secara bersama sama.

Penetapan wilayah di Kepulauan Riau sebagai kawasan perbatasan juga didasarkan delimitasi perbatasan negara dilaut dan keberadaan pulau terluar yang sekaligus menjadi titik penentu batas negara. Pulau terluar di Kepulauan Riau berdasarkan Keputusan Presiden Nomor 6 tahun 2017 berjumlah 22 pulau. Wilayah yang berada dilingkungan batas negara inilah yang kemudian dinyatakan sebagai kawasan berbatasan. Secara umum wilayah Kepulauan Riau merupakan provinsi yang berbatasan dengan sejumlah negara seperti Singapura, Malaysia dan Vietnam.

Berikut Peta Provinsi Kepulauan Riau dan 22 Pulau Terluar
Kawasan Perbatasan Kepulauan Riau memilik karakteristik berbeda dengan kawasan perbatasan lain di Indonesia. Jika wilayah lain kawasan perbatasannya melingkupi daratan, di Kepulauan Riau kawasan perbatasan negara ditandai oleh wilayah laut dan sebaran pulau disekitarnya. Kondisi geografis berupa kepulauan ini kemudian menjadi tantangan tersendiri bagi para stakeholder di Kepulauan bagaimana merumuskan agenda pembangunan yang memungkinkan dan dapat dilaksanakan untuk meningkatkan kesejahteraan rakyat termasuk di kawasan perbatasan.

Selama ini kebijakan pemerintah dalam pembangunan tidak serta merta menghasilkan akselerasi pembangunan pada setiap wilayah. Pilihan kebijakan memunculkan ketimpangan pembangunan antar wilayah. Minimnya pembangunan disuatu wilayah dapat dipengaruhi oleh pertimbangan efisiensi, politis, skala prioritas dan strategi pembangunan yang dipilih. Kondisi ini cenderung dialami oleh wilayah yang secara geografis sulit dijangkau seperti yang terjadi pada kawasan perbatasan negara, yaitu wilayah yang secara geografis jauh dari pusat pemerintahan, baik itu pusat pertumbuhan daerah yang ada di kabupaten/kota atau

Gambar 1 : Peta 22 Pulau terluar di Prov. Kepri

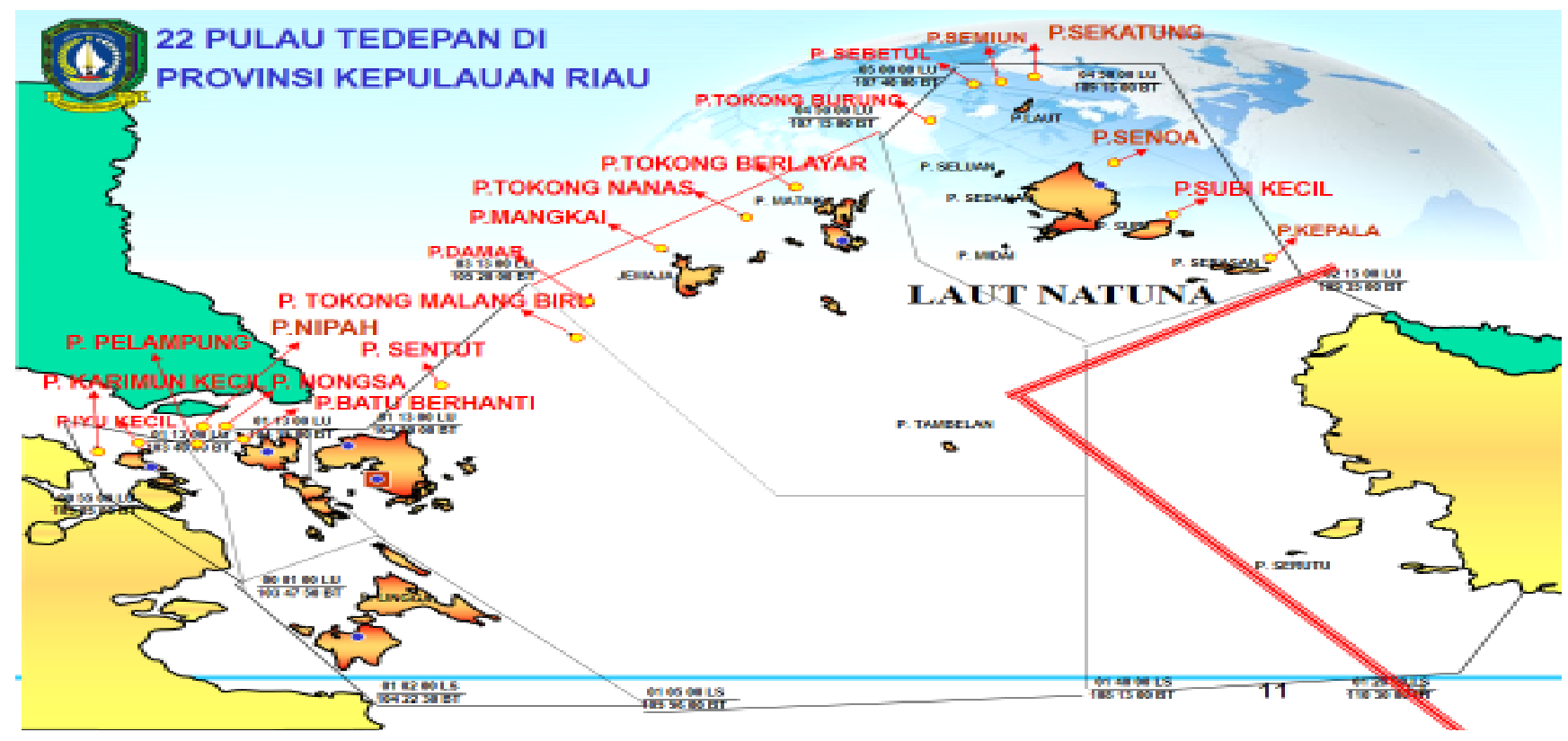


provinsi dan ibu kota negara. Geografis wilayah perbatasan negara umumnya adalah wilayahnya yang sulit dijangkau karena minim akses sarana transportasi dan perhubungan dan lainnya.

Komitmen pemerintah untuk membangunan kawasan perbatasan sempat menguat era pemerintahan Presiden Susilo Bambang Yudhoyono, hal itu ditandai dengan dibentuknya Badan Nasional Pengelola Perbatasan sebagai konsekuensi dan amanat disahkannya Undang-undang RI Nomor 43 Tahun 2008 tentang wilayah negara. Pada masa ini beberapa Provinsi yang wilayahnya berbatasan langsung dengan negara lain segera membentuk kelembagaan perbatasan daerah. Masa Pemerintahan Presiden Joko Widodo, semangat membangun kawasan perbatasan juga ditandai dengan dimasukkannya konsep pembangunan daerah pinggiran pada salah satu diantara 9 (Sembilan) pokok pikiran nawa cita pembangunan yakni cita ke 3 (tiga) "Membangun Indonesia dari pinggiran dengan memperkuat daerah-daerah dan desa dalam kerangka negara kesatuan". Melalui nawa cita-nya, Presiden Jokowi seolah menegaskan pentingnya pemerataan pembangunan diseluruh wilayah tanpa terkecuali.

Menguatnya isu perbatasan setidaknya menjadi poin dan momentum bagi Pemerintah Provinsi Kepulauan Riau untuk memperkuat arus pembangunan di kawasan perbatasan, tentu upaya ini mesti disertai upaya sehingga isu dan political will pemerintah untuk memberikan porsi pembangunan dikawasan perbatasan dapat berdampak langsung pada arus pembangunan dan peningkatan kesejahteraan masyarakat di kawasan perbatasan negara.

Adapun maksud kebijakan pengelolaan kawasan perbatasan sebagaiamana yang terdapat dalam rencana induk BNPP menyebut bahwa pengembangan wilayah kawasan perbatasan diarahkan untuk mewujudkan kemudahan aktivitas masyarakat kawasan perbatasan dalam berhubungan dengan negara tetangga dan pengelolaan sumber daya darat dan laut untuk menciptakan kawasan perbatasan yang berdaulat, sehingga terwujud halaman depan negara dan wilayah perbatasan yang mencerminkan NKRI aman, sejahtera, dan antisipatif terhadap perubahan global. Pengembangan infrastruktur diarahkan pada peningkatan konektivitas dengan membangun sistem jaringan jalan lokal di Kecamatan Lokasi Prioritas (Lokpri) dan antar Lokpri yang saling terhubung dengan pusat kegiatan ekonomi, serta pembangunan jalan non status pembuka akses menuju kampung, desa-desa di Kecamatan Lokpri. Oleh karena itu kawasan perbatasan oleh pemerintah disebut juga sebagai kawasan strategis dalam menjaga integritas wilayah negara yang memerlukan pengelolaan secara khusus. Meskipun disadari komitmen kebijakan pengelolaan kawasan perbatasan belum dapat diimplementasikan secara optimal karena berbagai kendala, baik dari sisi konsepsi pembangunan dan kebijakan yang perlu dibuat, maupun dari sisi sistem dan prosedur pengelolaan kawasan perbatasan yang berlaku. Hal ini tercermin, misalnya dari realitas masih kuatnya pendekatan sektoral, lemahnya sinergi antar sektor serta antara pusat dan daerah, serta belum terpadunya penanganan program pembangunan dikawasan perbatasan. (rinduk BNPP:15)

Kebijakan pengelolaan kawasan perbatasan negara secara formal merupakan sebuah kebijakan yang baru, sebab kebijakan perbatasan menguat seiring dengan disahkannya Undang-Undang RI Nomor 43 Tahun 2008 tentang Wilayah Negara. Menurut Edward III (1980 :150), kebijakan baru sulit diimplementasikan dengan sukses, penyebabnya adalah saluran komunikasi yang berkembang dengan baik belum ditetapkan, dan seringkali tujuan tidak jelas dan arahan tidak masuk akal. Ketika para pejabat harus menyiapkan program dari awal, mereka tidak selalu tahu apa yang harus dilakukan oleh implementator. Informasi tentang cara menjalankan program baru untuk mencapai tujuan baru mungkin kurang. 
Nugroho (2017) dalam bukunya Public Policy (Dinamika Kebijakan, Analisis Kebijakan, Manajemen Kebijakan) menyatakan hal yang paling penting dalam implementasi kebijakan haruslah menampilkan keefektifan dari kebijakan itu sendiri.

Kegagalan pemerintah dalam membangun kebijakan publik yang hebat atau unggul. Pertama, karena tidak mengerti makna dan substansi kebijakan publik. Ketidakmengertian ini bukan dominasi para praktisi pemerintahan, kalangan akademisi juga. Karena itu ancaman yang mungkin muncul adalah kemiskinan teori kebijakan publik. Kedua, karena analis kebijakan tidak ada, ada tetapi tidak bekerja dengan baik, dan kalaupun sudah bekerja dengan baik, tidak mampu menghasilkan kebijakan yang hebat. Mengapa? Guys B Peters (2004) mengatakan, "A great deal of policy formulation is done by inertia, by analogy, by intuition." Jadi karena begitu (merasa) ahli-nya, sipejabat pembuat kebijakan merasa tidak perlu melakukan proses analisis kebijakan yang sepatutnya dan dapat dipertanggungjawabkan. Mereka berubah dari "professional kebijakan publik" menjadi dukun kebijakan publik.

Dokumen RPJMD Provinsi Kepulauan Riau tahun 2016 - 2021 menyebut beberapa persoalan dalam pelaksanaan pembangunan di Kepulauan Riau, antara lain adalah masalah kesenjangan antar wilayah dan antar kelompok pendapatan yang cukup tinggi. Berdasarkan data BPS Kepri (2018) Jumlah penduduk miskin (Penduduk dengan pengeluaran per kapita per bulan di bawah garis kemiskinan) di Kepri mencapai mencapai 131.676 orang $(6,20$ persen) dibandingkan pada periode September 2017 yang mencapai 128.430 ribu pada September 2017 atau (6,13 persen) dari total penduduk Kepri yang mencapai 2.082.694 jiwa diakhir tahun 2017.

Di bidang infrastruktur, ketersediaan pelabuhan dan dermaga serta kapal pengangkut barang dan orang untuk mendukung konektivitas antar pulau masih sangat kurang. Begitu pula dengan jaringan telekomunikasi di beberapa pulau berpenghuni ketersedian jaringan telekomunikasi masih minim.

Implementasi kebijakan pengelolaan kawasan perbatasan yang dikaji pada penelitian ini adalah, bagaimana Pemerintah Provinsi Kepulauan Riau dalam mengimplementasikan kebijakan pengelolaan kawasan perbatasan negara, sehingga political will pemerintah dalam membangun kawasan perbatasan, dapat menjadi modal dasar sebagai bentuk komitmen pemerintah untuk memperkuat pembangunan kawasan perbatasan melalui rumusan kebijakan yang dibuat untuk mewujudkan sinergisitas kebijakan pemerintah pusat dan penguatan pelaksanaan pembanguan kawasan perbatasan oleh daerah.

Esensi utama dari implementasi kebijakan adalah memahami apa yang seharusnya terjadi sesudah suatu program dinyatakan berlaku atau dirumuskan. Pemahaman tersebut mencakup usaha untuk mengadministrasikannya dan menimbulkan dampak nyata pada masyarakat atau kejadian-kejadian. George C. Edward III (1980: 10) yang mengembangkan model implementasi kebijakan yang berspektif top down menamakan model implementasi kebijakan publiknya dengan Direct and Indirect Impact on Implementation. Menurut Edward III kebijakan publik didefinisikan sebagai "What governments say and do, or do not do. It is the goals or purposes of governments programs." Maksudnya, apa yang dinyatakan dan dilakukan atau tidak dilakukan oleh pemerintah termasuk kebijakan publik.

Dalam pendekatan teorinya Edward III yang akan pakai sebagai alat analis implementasi kebijakan dalam penelitian ini. Edward III mengatakan bahwa pelaksanaan implementasi dapat berhasil dengan baik harus didukung empat faktor, yaitu komunikasi, sumber daya, disposisi pelaksana dan struktur birokrasi. Sesuai dengan teori implementasi yang menjadi landasan dalam penelitian ini, maka definisi konseptual penelitian implementasi kebijakan ini adalah pelaksanaan kebijakan yang mencakup 
penyelenggaraan komunikasi, dukungan sumber daya, struktur birokrasi, disposisi pelaksana. Kerangka teori yang akan dibangun pada penelitian ini adalah teori kebijakan publik dan implementasi kebijakan Pengelolaan Kawasan Perbatasan di Kepulauan Riau.

Dye dalam Sri Suwitri Dkk (2016:1.7) mengungkap bahwa kebijakan publik dapat dilihat sebagai apa pun yang pemerintah pilih untuk dilakukan atau tidak dilakukan. Harold D Laswell dan Abraham Kaplan mengemukakan pengertian kebijakan publik sebagai suatu program pencapaian tujuan, nilai-nilai dan praktek-praktek yang terarah.

Anderson (1994:6) mengartikan kebijakan publik sebagai kebijakan-kebijakan yang dibuat oleh lembaga atau pejabat pemerintah. Menurut Anderson terdapat 5 (lima) implikasi dari konsep mengenai kebijakan publik. Pertama, kebijakan publik adalah tindakan yang berorientasi tujuan. Kedua, kebijakan publik berisikan rangkaian tindakan yang diambil sepanjang waktu. Ketiga, kebijakan publik merupakan tanggapan dari kebutuhan akan adanya suatu kebijaan mengenai hal-hal tertentu. Keempat, kebijakan publik merupakan gambaran dari kegiatan pemerintah senyatanya, dan bukan sekedar keinginan yang akan dilaksanakan. Kelima, kebijakan pemerintah dapat merupakan kegiatan aktif atau pasif dalam menghadapi suatu masalah.

Tujuan akhir kebijakan publik adalah tentang bagaimana suatu negara mencapai cita-citanya. Implementasi kebijakan akan diketahui bagaimana out put kebijakan yang telah diputuskan terealisasi. Menurut Purwanto dan Sulistyastuti (2012:21), implementasi intinya adalah kegiatan untuk mendistribusikan keluaran kebijakan (to deliver policy output) yang dilakukan oleh para implementator kepada kelompok sasaran (target group) sebagai upaya untuk mewujudkan kebijakan.

Menurut Van Metter dan Van Horn dalam Agustino (2008: 195) bahwa implementasi kebijakan adalah tindakan-tindakan yang dilakukan baik oleh individu-individu/ pejabat- pejabatataukelompok-kelompokpemerintahatau swasta yang diarahkan pada tercapainya tujuantujuan yang telah digariskan dalam keputusan kebijakan. Implementasi merupakan suatu proses yang dinamis dimana pelaksana kebijakan melakukan suatu aktivitas atau kegiatan, sehingga pada akhirnya akan mendapatkan suatu hasil yang sesuai dengan tujuan atau sasaran kebijakan itu sendiri. Implementasi kebijakan merupakan tahap yang krusial dalam proses kebijakan publik. Suatu kebijakan atau program harus diimplementasikan agar mempunyai dampak atau tujuan yang diinginkan. Implementasi kebijakan dipandang dalam pengertian luas merupakan alat administrasi publik dimana aktor, organisasi, prosedur, teknik serta sumber daya diorganisasikan secara bersama-sama untuk menjalankan kebijakan guna meraih dampak atau tujuan yang diinginkan.

Pengelolaan kawasan perbatasan pada aspek lain sesungguhnya terkait dengan persoalan desentralisasi dan sentralisasi pemerintahan. Sentralisasi lebih dipengaruhi bahwa kawasan perbatasan terkait dengan status kedaulatan wilayah negara secara keseluruhan. Sementara desentralisasi terkait kewenangan pemerintah daerah untuk mengelola sendiri wilayahnya menjadi lebih baik dan dapat bersaing baik dari sisi pembangunan dan kesejahteraan.

Menurut Eko Prasojo (2016), Sentralisasi dan desentralisasi dalam ranah pemerintahan adalah sebuah kontinum bukan sebuah dikotomis. Sebagai sebuah kontinum, setralisasi tidak berada dalam ruang yang vakum atau ruang yang kosong. Sentralisasi dan desentralisasi selalu bergerak dari satu titik pendulum ketitik pendulum yang lain. Hal yang sama terjadi dalam konteks negara. Penyelenggaraan pemerintahan merupakan kombinasi kekuatan yang bersifat sentripetal (sentralisasi) dan kekuatan sentrifugal (desentraliasi) secara bersamaan. Tidak ada negara yang hanya diselenggarakan secara sentralisasi, sekalipun selalu terdapat beberapa kewenangan yang hanya diselenggarakan secara sentralisasi saja. Sebaliknya, tidak ada satu negara yang menyelenggarakan pemerintahannya 
secara desentralisasi saja sehingga tidak terdapat pengaturan yang bersifat nasional.

Dalam makalah berjudul perlu disentralisasi asimetris, Prof. M Mas'ud Said, Ph.D. menyatakan untuk kasus Indonesia model desentralisasi asimetris perlu menjadi perhatian, sebab melalui pola ini dapat terbukanya ruang gerak implementasi dan kreatifitas daerah Provinsi dalam pelaksanaan pemerintahan di luar ketentuan umum dan khusus. Mengapa provinsi? Ini karena level kabupaten dan kota sudah cukup terakomodasi dalam perundangan pemerintahan selama ini.

Prof. Eko Prasojo ketika menyampaikan pidato pengukuhan sebagai guru besar ilmu administrasi FISIP UI tahun 2006 mengungkapkan bahwa konstruksi hubungan pusat dan daerah pada masa yang akan datang diarahkan pada dua hal, yakni fungsi mengatur dan mengurus. Dalam praktek di negara-negara kesatuan, model pembagian kewenangan yang dianut adalah berdasarkan fungsi. Titik berat fungsi mengatur yang bersifat nasional dilakukan oleh pusat. Sedangkan Propinsi dan Kabupaten/ Kota mengatur sesuai dengan tingkat kewenangan yang dimiliki. Selaras dengan kewenangan mengatur yang dimiliki, fungsi mengurus dilakukan oleh masing-masing tingkatan sesuai dengan kewenangan yang dimiliki.

Dalam konteks Indonesia pelaksanaan desentralisasi sebagai upaya otonomi daerah, Djohermansyah Djohan (2014) menyebut pelaksanaan otonomi daerah selama ini adalah otonomi setengah hati. Kendala yang muncul dalam implementasi otonomi daerah adalah persoalan teknis dan politis. Kendalateknis berupa belum memadainya peraturan pelaksanaan yang dibuat pemerintah pusat seperti banyaknya peraturan menyangkut otonomi daerah yang tidak jelas. Kendala politis terkait kesungguhan political will dan pemerintah tampak setengah hati melaksanakan otonomi daerah.

Penelitian ini dimaksudkan untuk menganalisis apa dan bagaimana implementasi kebijakan pengelolaan kawasan perbatasan di Provinsi Kepulauan Riau sehingga political will pemerintah dalam membangun kawasan perbatasan, dapat menjadi modal dasar memperkuat pembangunan kawasan perbatasan negara seperti melakukan sinergisitas dalam mengimplementasikan kebijakan pengelolaan kawasan perbatasan negara bersama pemerintah pusat, bersama pemerintah daerah itu sendiri, maupun pihak lain yang berkepentingan. Fokus perhatian pada penelitian ini adalah implementasi kebijakan pengelolaan kawasan perbatasan negara di Provinsi Kepulauan Riau.

\section{METODE}

Penelitian ini menggunakan metode penelitian deskriptif dengan menggunakan analisis yang bersumber dari data kualitatif. Analisis data dilakukan dengan cara mendeskripsikan aspek-aspek yang berhubungan dengan implementasi kebijakan kawasan perbatasan negara oleh Pemerintah Propinsi Kepulauan Riau berdasarkan data yang telah dikumpulkan, baik melalui dokumentasi, wawancara, sumber informasi seperti pejabat dan informan lainnya dengan teknik pengambilan data purposive sampling.

\section{PEMBAHASAN}

Secara umum Luas wilayah Kepri meliputi 241,215 Km2. Menyandang status sebagai Provinsi Kepulauan dengan topografi wilayah yang terdiri dari gugusan pulau yang saling terpisah oleh lautan, komposisi perairan di Kepri lebih luas dibanding daratan. Dinyatakan bahwa luas daratan di Kepulauan Riau meliputi 4 (empat) persen, sisanya 96 persen berupa wilayah laut. Populasi penduduk menyebar pada sejumlah pulau utama. Dari 2.408 pulau yang ada di Kepulauan Riau, pulau yang berpenghuni hanya berkisar 300-an saja.

Dokumen rencana induk Badan Nasional Pengelola Perbatasan (BNPP) tahun 2015-2019, menempatkan 41 kecamatan yang tersebar di 5 (lima) wilayah dari 7 kabupaten/kota yang ada di Kepulauan Riau sebagai lokasi prioritas (Lokpri) 
pembangunan kawasan perbatasan. Banyaknya titik perbatasan dan wilayah yang menjadi kawasan perbatasan di Kepri, menempatkan Kepulauan Riau sebagai Provinsi yang memiliki status kawasan kecamatan perbatasan negara terbanyak di Indonesia.

Adapun wilayah Kepulauan Riau yang telah ditetapkan sebagai kawasan perbatasan negara berdasarkan Rinduk BNPP tersebar pada 5 (lima) kabupaten/kota yang meliputi:
Nomor : 26 Tahun 2008 tentang rencana tata ruang nasional juga menetapkan Kota Batam dan Ranai Kabupaten Natuna,sebagai PKSN (Pusat Kegiatan Strategis Nasional) di Provinsi Kepri (Lampiran II).

Di Provinsi Kepulauan Riau ditetapkan 2 (dua) Kawasan Strategis Nasional, yaitu : Kawasan Perbatasan Laut RI termasuk 22 pulau kecil terdepan yang terletak di Provinsi Kepulauan Riau berdasarkan Kepres Nomor 6 Tahun 2017 Tentang Penetapan Pulau-Pulau Kecil Terluar

Tabel 3. Lokasi Prioritas Kecamatan Kawasan Perbatasan di Kepulauan Riau

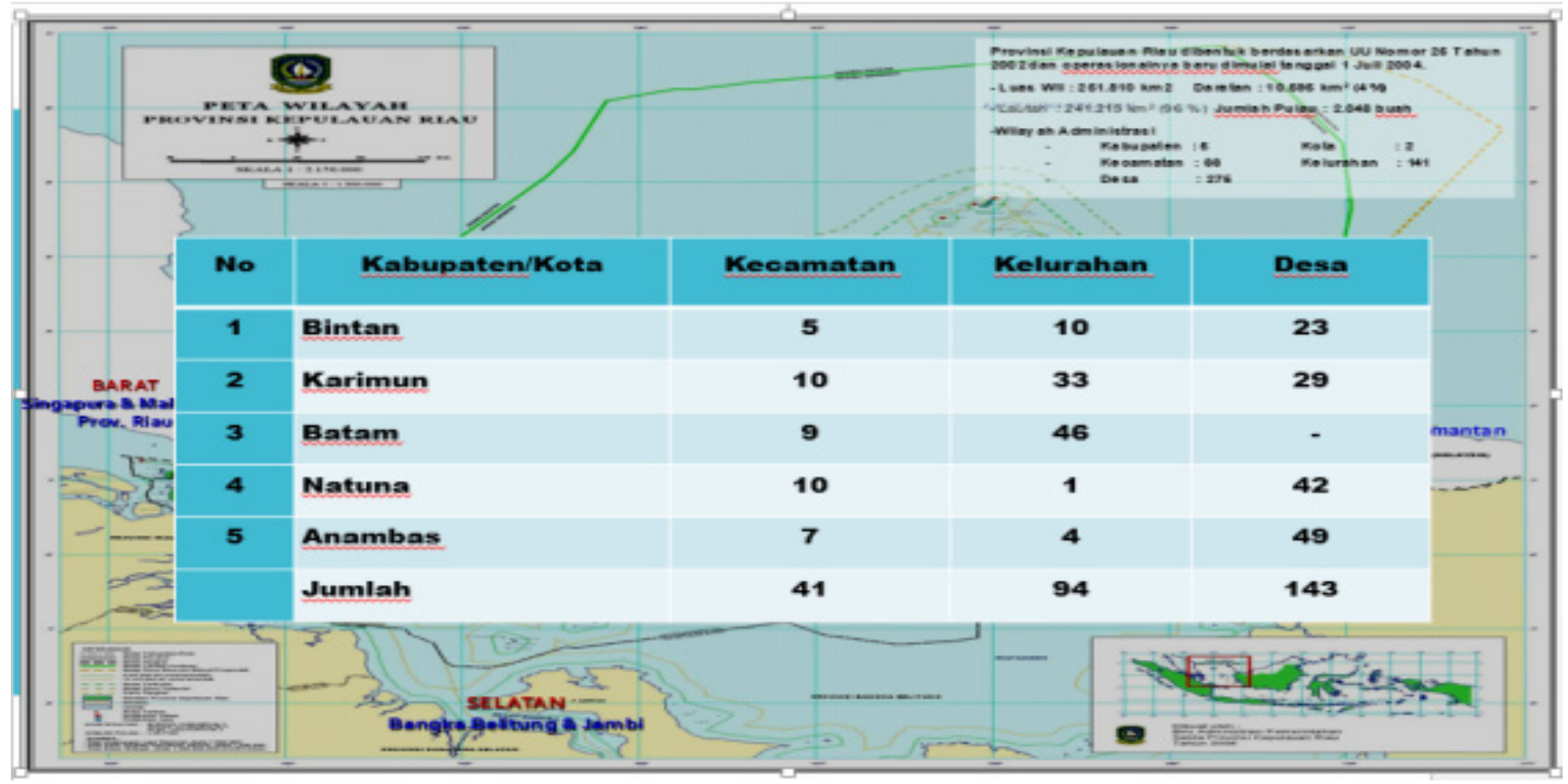

Berdasarkan data diatas, persentase wilayah Provinsi Kepulauan Riau yang ditetapkan sebagai kawasan perbatasan mencapai lebih dari lima puluh persen wilayah kecamatan yang ada, sebab dari 70 kecamatan yang ada di Kepulauan Riau 41 Kecamatan sebagai lokasi prioritas nasional pembangunan kawasan perbatasan negara. Banyaknya wilayah yang menjadi kawasan perbatasan di Kepri, menempatkan Kepulauan Riau sebagai Provinsi yang memiliki status kawasan perbatasan terbanyak di Indonesia.

Selain menetapkan beberapa wilayah sebagai lokasi prioritas kawasan perbatasan, Peraturan Pemerintah Republik Indonesia
(Pulau Sentut, Tokong Malang Biru,

Damar, Mangkai, Tokong Nanas, Tokong Belayar, Tokong Boro, Semiun, Sebetul, Sekatung, Senua, Subi Kecil, Kepala, Iyu Kecil/ Tokong Hiu Kecil, Karimun Kecil/Karimun Anak, Nipa, Pelampong, Batu Berhanti/Batu Berantai, Nongsa/Putri, Pulau Berakit, Pulau Bintan, Pulau Malang Berdaun) dengan negara Malaysia/Vietnam/Singapura; Dan Kawasan Batam, Bintan, dan Karimun sebagai Kawasan Perdagangan Bebas dan Pelabuhan Bebas.

Kawasan strategis nasional adalah wilayah yang penataan ruangnya diprioritaskan karena mempunyai pengaruh sangat penting 
secara nasional terhadap kedaulatan negara, pertahanan dan keamanan negara, ekonomi, sosial, budaya, dan/atau lingkungan, termasuk wilayah yang ditetapkan sebagai warisan dunia. PKSN adalah kawasan perkotaan yang ditetapkan untuk mendoroang pengembangan kawasan perbatasan negara. Selanjutnya disebutkan dalam pasal 9 PP Nomor 26/2008 huruf $\mathrm{g}$ bahwa kebijakan pengembangan kawasan strategis nasional dimaksudkan sebagai upaya pengembangan kawasan tertinggal untuk mengurangi kesenjangan tingkat perkembangan antar kawasan.

Diantara tiga kawasan strategis nasional di Kepri yang meliputi Batam, Bintan dan Karimun, khususnya Batam setidaknya sudah menunjukkan pengaruh sebagai pusat pertumbuhan yang memberikan effect domino pertumbuhan ekonomi bagi daerah sekitar, bahkan menjadi penyokong pertumbuhan ekonomi nasional. Keberadaan Kota Batam ini setidaknya sudah mampu menjawab keinginan pemerintah menjadikan kawasan perbatasan sebagai beranda depan negara di Kepri, sebaliknya wilayah kabupaten/kota lain di Kepulauan Riau masih perlu mendapat stimulus program/ kegiatan pembangunan yang lebih intensif.

Namun eksistensi Kota Batam sehingga mampu menjadi pusat pertumbuhan tidak lepas dari kebijakan dan sentuhan pemerintah pusat yang secara serius memberikan perhatian dengan menjaga eksistensi sebuah badan pengelola dengan memberikan kewenangannya kepada Badan Pengelola Pulau Batam dalam bentuk Otorita Batam yang dalam pelaksanaan tugasnya, lembaga ini memiliki kewenangan penuh untuk mengatur, pengelolaan, mengembangakan dan membangun kawasan Pulau Batam dan sekitar sesuai dengan fugsinya dan langsung bertanggunjawab kepada presiden, sekarang lembaga ini dikenal dengan Badan Pengusahaan Batam..

Kebijakan politik pemerintah yang kembali menguatkan isu pembangunan kawasan perbatasan pasca era reformasi telah memberikan peluang bagi sejumlah kawasan di Kepulauan Riau untuk mendapat perhatian pembangunan. Isu Perbatasan menjadi momentum bagi Kepulauan Riau, khususnya kabupaten/kota yang wilayahnya ditetapkan sebagai kawasan perbatasan untuk menjadikan wilayahnya sebagai target dan objek pembangunan yang lebih diperhatikan terutama mengikat kebijakan top down dalam pembangunan didaerah.

Fokus Pengembangan Kawasan Perbatasan diarahkan pengembangan Pusat Kegiatan Strategis Provinsi (PKSN) serta percepatan pembangunan di Kecamatan Lokasi Prioritas (Lokpri). Sedangkan PKSN sebagaimana aturan pasal 15 PP No 13/2017 tentang perubahan atas PP No. 26 tahun 2008 tentang rencana tata ruang wilayah nasional bahwa PKSN ditetapkan dengan maksud dan kriteria;

Secara nasional, kebijakan pengelolaan perbatasan muncul seiring diberlakukannya Undang-Undang Nomor 43 Tahun 2008 tentang wilayah negara dan kemudian disusul dengan terbitnya Peraturan Presiden Nomor 12 tahun 2010 tentang pembentukan Badan Nasional Pengelola Perbatasan, serta keluarnya Peraturan Menteri Dalam Negeri Nomor 2 Tahun 2011 tentang Pedoman Pembentukan Badan Pengelola Perbatasan di Daerah.

Analisis implementasi kebijakan dalam pengelolaan kawasan perbatasan negara di Provinsi Kepulauan Riau dalam penelitian ini menggunakan analisis kebijakan model Implementasi Edward III yang mengukur implementasi kebijakan dengan 4 aspek yaitu komunikasi, sumber daya, disposisi dan stuktur birokrasi.

\section{Komunikasi}

Berdasarkan informasi yang diperoleh dari informan Kepala Bagian Perbatasan pada Biro Pemerintahan dan Perbatasan Provinsi Kepri, menyebut komunikasi terkait penerimaan dan penyampaian program perbatasan secara formal dilaksanakan melalui rapat koordinasi (rakor/raker), konsultasi atau melalui forum 
sosialisasi bersama pemerintah daerah dan pusat.

Bersama pemerintah pusat, penerimaan informasi terkait kebijakan perbatasan dilakukan seperti dengan menghadiri pertemuan koordinasi perbatasan yang rutin dilaksankan oleh pemerintah pusat melalui BNPP selaku regulator tingkat nasional dan menjadi induk atas sesuatu yang menjadi pedoman kebijakan perbatasan, termasuk bagaimana penerapannya didaerah. "Selain mengikuti rakor, kita melakukan konsultasi dan koordinasi dengan cara datang langsung kepada pejabat di BNPP sesuai kebutuhan dengan tujuan memperkuat pemahaman termasuk melakukan sinkronisasi program dan kegiatan perbatasan di daerah"(Wawancara dengan Kepala Bagian Perbatasan Prov. Kepri 12 November 2018).

Sementara itu beberapa upaya mengkomunikasikan kebijakaan perbatasan di daerah, informan menyebut antara lain dilaksanakan seperti melakukan rapat/ pertemuan, konsultasi mandiri, sosialisasi program perbatasan dalam bentuk pertemuan, serta dengan melakukan rapat koordinasi (rakor) perbatasan dengan cara mengundang SKPD teknis yang dianggap memiliki keterkatitan langsung dengan pembangunan kawasan perbatasan dalam sebuah rapat koordinasi khusus (rakor perbatasan) pembangunan di perbatasan.

Menurut Informan, pelaksanaan rakor ataupun koordinasi dan konsultasi merupakan upaya menjalin komunikasi dengan stake holder pengelolaa perbatasan dan sejalan dengan tupoksi lembaga perbatasan daerah yang meliputi, pelaksanaan koordinasi penyusunan program, koordinasi penyusunan anggaran dan koordinasi, monitoring pengawasan, seperti dinyatakan berikut:

"Kita sebagai unit yang memiliki tupoksi perbatasan, selama ini penyampaian dan penerimaan kebijakan perbatasan oleh pemerintah pusat kepada daerah, termasuk penyampaian kebijakan didaerah, berdasarkan tupoksinya, sudah mengikuti garis kebijakan dan wewenang yang menjadi tugas bagian perbatasan. Hanya saja kebijakan perbatasan belum menjadi spirit pada tingkat implementasi dilevel teknis". (Wawancara dengan Kepala Bagian Perbatasan Prov. 12 November 2018).

Berdasarkan Informasi saat wawancara, ada harapan dari pelaku kebijakan bahwa hasil rapat koordinasi kelembagaan perbatasan, seharusnya dapat menjadi pedoman, diikuti dan dilaksanakan oleh lembaga teknis. Lembaga perbatasan dalam konteks koordinasi lebih diarahkan pada sinkronisasi program dan kegiatan yang memang diarahkan untuk dapat dilaksanakan sebagai upaya percepatan pembangunan di perbatasan. "Tetapi kita belum memiliki daya dorong kepada pelaksana organisasi perangkat daerab (opd) teknis seperti dinas atau lembaga lain untuk mendesakkan kebijakan perbatasan agar hasil rakor menjadi usulan kegiatan oleh OPD yang secara teknis memiliki kewenangan eksekusi pembangunan. Rakor perbatasan, masih terlihat sebagai upaya mengkaji program dan menghimpun kegiatan yang dilakukan OPD pada wilayah yang ditetapkan sebagai kawasan perbatasan sebagaimana Lokpri. Jadi kalupun ada rakor, hasilnya masih seperti lembaga pengumpul data/kegiatan dan usulan. Kesannya bukan menyusun apalagi merumuskan, tetapi masih mengumpulkan," (Wawancara dengan Kepala Bagian Perbatasan Prov. Kepri 12 November 2018).

Menurut sumber informasi saat dilakukan wawancara, agar terbangun persepsi yang sama dalam mewujudkan kebijakan perbatasan dan diikuti oleh pelaksana dilevel teknis, maka komunikasi yang perlu dibangun dan di perkuat adalah bagaimana komunikasi antar elit tertinggi baik pusat dan daerah, tetapi juga dituangkan dalam kebijakan kongkrit dalam dokumen perencanaan atau lainnya sehingga melalui kebijakan yang disepakati terdapat poin yang dapat dipatuhi oleh kementerian lembaga (KL) atau OPD di daerah dalam mendukung upaya pembangunan di perbatasan.

"Ada perintah, ada indikator. Semua 
instrument perlu disiapkan, terutama bagaimana soal pendanaan. Pembangunan di perbatasan ini berat, campur tangan pemerintah pusat sangat diperlukan. Perintah-perintah ini akan mudah dilaksanakan jika pimpinan sudah memutuskan." (Wawancara dengan Kabag Perbatasan Prov. Kepri 12/11/2018).

Disebutkan bahwa kebijakan perbatasan banyak instrument yang terlibat. Untuk itu diperlukan adanya keterikatan para pihak agar dapat terikat untuk melaksanakan political will dan kebijakan yang dituangkan dalam program berdasarkan indikator dan dilaksanakan dalam kegiatan. "Saya kira kalau setiap SKPD mencantumkan perbatasan sebagai indikator, akan lebih mudah proses koordinasi dan pelaksanaan kebijakan perbatasan.” (Wawancara dengan Kabag Perbatasan Prov. Kepri 12/11/2018).

Seperti disampaikan kasubag keuangan dan perencanaan Dinas Pekerjaan Umum dan Pertanahan Provinsi Kepri bahwa pelaksanaan program dan kegiatan yang dilakukan pada dinasi pekerjaan umum sudah memiliki landasan kerja berdasarkan rencana kerja yang sudah ada. "Kami tidak melihat apakah itu wilayah perbatasan atau bukan. Ketika sebuah usulan menjadi kebutuhan permbangunan karena infrastruktur diwilayah diperlukan, dan kegiatan itu telah sesuai dan mengikuti mekanisme perencanaan dan penganggaran, tentu berdasarkan prosedur itulah lembaga ini bekerja dan kegiatan itu dapat dilaksanakan.” .” (Wawancara dengan Kasie Perencanaan dan Keuangan Dinas PU Prov. Kepri 16/11/2018)

Sumber informan lain menyebut bahwa kebijakan pemerintah dalam menetapkan lopkri belum disertai dengan dukungan teknis, terutama terkait alokasi dana sehingga pelaksanaan pengembangan dan pengelolaan perbatasan dapat dilakukan.

"Memang ada program DAK (dana alokasi khusus) Afirmasi oleh pemerintah pusat kepada daerah, yang dialokasikan untuk katagori tertinggal, kepulauan dan perbatasan, tetapi secara teknis lembaga perbatasan belum memiliki akses yang cukup terkait program tersebut. Kadang setelah rapat baru kita tahu kabupaten A dan kecamatan B mendapat program kegiatan. Tetapi bagaiamna proses sehingga dana pusat itu dapat turun ke daerah, kita tidak tahu persis bagaimana prosesnya. Dan itu biasanya dari kementerian lembaga yang pelaksanaannya dilaksanakan OPD terkait. Juga tidak semua Lokpri dapat," (Wawancara dengan Kassubag batas negara Prov. Kepri 12/11/2018)

Mengutip Husnadi dalam tesisnya (2006) menyebutiklim pembangunan di Indonesiabelum sepenuhnya menganggap kawasan perbatasan sebagai kawasan prioritas, meskipun dalam berbagai kesempatan disebutkan bahwa kawasan perbatasan merupakan "beranda depan" negara. Namun pada kenyataannya mengubah suatu paradigma dalam implementasinya ternyata tidak mudah.

Menurut Winarno (2005:128), Faktorfaktor yang mendorong ketidakjelasan dalam implementasi kebijakan publik biasanya karena kompleksitas kebijakan, kurangnya konsensus mengenai tujuan-tujuan kebijakan publik, adanya masalah-masalah dalam memulai kebijakan yang baru serta adanya kecenderungan menghindari pertanggungjawaban kebijakan.

Dalam aspek komunikasi ini, teori implementasi kebijakan Edward III menyebut adanya keterkaitan pada beberapa hal:

\section{1) Transmisi}

Transmisi yang terkait implementasi kebijakan pengelolaan kawasan perbatasan di Kepulauan Riau, secara tupoksi dijalankan oleh bagian perbatasan, khususnya oleh Sub Bagian Batas Negara yang secara teknis menjalankan tugas pada pelaksanaan program dan kegiatan.

Secara kelembagaan formalitas peran transmisi ini tertuang pada tupoksi perbatasan sebagaimana dalam pergub Nomor 59 Tahun 2017 Tentang Kedudukan, Susunan Organisasi, Tugas Dan Fungsi, Serta Tata Kerja Perangkat Daerah bahwa Bagian Perbatasan 
mempunyai tugas menyiapkan penyusunan dan perumusan rencana induk dan rencana aksi, serta pengoordinasian penyusunan kebijakan, pelaksanaan koordinasi penyusunan anggaran pembangunan, pelaksanaan pembangunan, serta pemanfaatan perbatasan antar negara, perbatasan antar daerah pengendalian,pengawasan, evaluasi dan pelaporan pengelolaan batas negara wilayah darat, laut dan udara.

Dalam upaya menggunakan kapasitasnya sebagai transmisi, Sub Bagian Batas Negara idealnya mampu menjalankan peran sehingga dapat memberikan persepsi positif kepada setiap stake holder terkait kebijakan pengelolaan perbatasan di daerah khususnya di Provinsi Kepulauan Riau dan Pemerintah Pusat, sehingga terbangun komitmen dan keselarasan kebijakan antar lembaga yang terkait pengelolaan kawasan perbatasan dapat saling bersinergi dengan memberikan perhatian pada pembangunan kawasan perbatasan di Provinsi Kepulauan Riau.

Kepiawaian menjalankan transmisi akan berpengaruh pada kebijakan pengelolaan kawasan perbatasan negara tersampaikan sehingga kebijakan terkait pengelolan kawasan perbatasan dipahami dan menjadi tanggungjawab bersama.

"Kita belum sampai pada 'mewajibkan' mereka (opd) untuk berbuat pada kawasan perbatasan. Persoalannya, Kepri sebagai kawasan perbatasan belum memiliki rencana induk perbatasan. Saat rakor kita minta usulan atau kegiatan yang ada di kecamatan, termasuk SKPD teknis. Pada tahap ini kita masih seperti lembaga pengumpul data saja." (Wawancara dengan Kabag Perbatasan Prov. Kepri 12/11/2018).

Kemampuan menjadi transmisi juga akan mendukung tersalurkannya agregasi dan terartikulasinya kepentingan-kepentingan terkait kebijakan pengelolaan kawasan perbatasan termasuk pada beberapa kelompok interest terkait kebijakan kawasan perbatasan. Informan Kassubag Batas Negara menyebut bahwa pelaksanaan transmisi cukup berat untuk dilaksanakan oleh pejabat selevel eselon
IV dengan hanya dukungan 2 (dua) orang staf pelaksana. "Walaupun dalam banyak hal didukung oleh Kabag selaku eselon III. Namun secara teknis pelaksanaan tugas tetap bertumpu pada staf pelaksana. Kami disini hanya bertiga, termasuk saya. Keterbatasan bukan saja dari sisi SDM, selama beberapa tahun ini kegiatan masih terbatas pada rutinitas seperti koordinasi, tetapi belum mampu menguatkan kebijakan bagaimana pengembangan ataupun kegiatan perbatasan dilaksanakan, apalagi teknis kegiatan tidak pada bagian perbatasan.” (Wawancara dengan Kabag Perbatasan Prov. Kepri 12/11/2018)

2) Kejelasan informasi.

Kejelasan informasi yang diterima oleh para pelaksana kebijakan harus jelas dan tidak membingungkan. Sebagai leading sector pengelolaan perbatasan, bagian perbatasan harus memiliki referensi dan informasi yang akurat terkait kebijakan pemerintah. Dalam hal pelaksanaan tugasnya terkait informasi kebijakan perbatasan diperoleh melalui forum pertemuan dengan pemangku kepentingan baik di pusat maupun antar daerah. Informasi yang didapat misalnya dilakukan pada rapatkonsultasi dan koordinasi, diskusimelalui FGD (forum group discussion), ataupun dialog terkait pembangunan dan pengelolaan kawasan perbatasan.

Kepala bagian perbatasan selaku informan dalam penelitian ini menyatakan bahwa kebijakan pengelolaan perbatasan selain diperoleh melalui referensi seperti buku dan dokumen lainnya, juga dipahami melalui kegiatan koordinasi dengan pemerintah pusat terutama Badan Nasional Pengelola Perbatasan atau melalui forum rakor antar stake holder yang ada di daerah. "Kunjungan pada daerah perbatasan lain juga kita lakukan sebagai upaya menambah khasanah kita dalam pelaksanaan kebijakan perbatasan. Informasi itulah yang kemudian kita sampaikan saat rakor atau pertemuan lainnya di daerah"." (Wawancara dengan Kabag Perbatasan Prov. Kepri 12/11/2018). 


\section{3) Konsistensi}

Menurut Edward III, perintah yang diberikan dalam pelaksanaan suatu komunikasi harus konsisten dan jelas untuk ditetapkan atau dijalankan.Jika perintah yang diberikan sering berubah-ubah, maka dapat menimbulkan kebingungan bagi pelaksana di lapangan. Oleh karena itu konsistensi juga harus mendapat perhatian dalam sebuah komunikasi. Konsistensi dalam implementasi kebijakan pengelolaan kawasan perbatasan dapat meningkatkan kepercayaan publik pada political will pemerintah terhadap kebijakan pengelolaan kawasan perbatasan.

Ketika wawancara dilakukan, dinyatakan bahwa konsistensi kebijakan menjadi pembuktian keseriusan pemerintah untuk melakukan pembangunan yang lebih baik pada kawasan perbatasan. Diungkapkan bahwa secara political will pemerintah sudah memiliki keinginan yang kuat mewujudkan pembangunan kawasan perbatasan, tetapi pada tataran praktis, implementasi kebijakan mendapat hambatan, baik secara sistem maupun struktural birokrasi.

Saat dilakuan wawancara, informan mengakui bahwa sistem perencanaan belum mendukung subbag batas negara untuk menkoordinasikan kebijakan pengelolaan kawasan perbatasan. "Tolak ukur kebijakan pengelolaan kawasan perbatasan belum menjadi indikator pelaksanaan pemerintahan. Ya di organisanasi kita capaian pelaksanaan perbatasan tidak masuk dalam akuntabilitas kinerja," (Wawancara dengan Kassubag Perbatasan Prov. Kepri 12/11/2018)

Jika melihat indikator pencapai misi organisasi, berdasarkan dokumen sistem akuntabilitas kinerja, terlihat bahwa capaian kebijakan pengelolaan kawasan perbatasan belum menjadi bagian dari sasaran pada misi yang harus dicapai, terutama dalam dokumen laporan akhir Laporan Akuntabilitas Kinerja (Lakip). Padahal sistem akuntabilitas kinerja instansi pemerintah (SAKIP) merupakan perwujudan kewajiban suatu instansi pemerintah untuk mempertanggungjawabkan keberhasilan dan kegagalan pelaksanaan misi organisasi dalam mencapai sasaran dan tujuan yang telah ditetapkan melalui sistem pertanggungjawaban secara periodik.

Berikut tabel tujuan, sasaran indikator kinerja Biro Pemerintahan dan Perbatasan berdasarkan ssstem akuntabilitas capaian kinerja. Indikator Kinerja berdasarkan tujuan, sasaran jangka menengah Biro Pemtas Tahun 2016-2021:

Tabel 1 Indikator Kinerja Biro Pemerintahan

Sumber Lakip biro pemerintahan dan perbatasan tahun 2017

\begin{tabular}{|c|c|c|c|}
\hline NO & TUJUAN & $\begin{array}{l}\text { SASARAN SRAT- } \\
\text { EGIS }\end{array}$ & $\begin{array}{l}\text { INDIKATOR KIN- } \\
\text { ERJA }\end{array}$ \\
\hline (1) & (2) & (3) & (4) \\
\hline 1 & $\begin{array}{l}\text { Mewujudkan } \\
\text { Administrasi } \\
\text { Pemerintahan } \\
\text { Umum dan } \\
\text { Otonomi Dae- } \\
\text { rah yang opti- } \\
\text { mal }\end{array}$ & $\begin{array}{l}\text { Terwujudnya pe- } \\
\text { nyelenggaraan } \\
\text { pem erintahan } \\
\text { yang akuntabel }\end{array}$ & $\begin{array}{l}\text { Peringkat LPPD } \\
\text { Provinsi }\end{array}$ \\
\hline & & & $\begin{array}{l}\text { Persentase Peny- } \\
\text { elenggaraan Tata } \\
\text { Kelola Pemerin- } \\
\text { tahan Daerah }\end{array}$ \\
\hline
\end{tabular}

Berdasarkan indikator kinerja ini terlihat bahwa pencapaian kinerja Biro Pemerintahan dan Perbatasan yang secara nyata bertanggunjawab atas pelaksanaan tugas kebijakan perbatasan negara belum mengakomodir isu dan kebijakan pengelolaan kawasan perbatasan, padahal dalam materi RPJM-nya, pemerintah Kepri memasukkan persoalan perbatasan negara sebagai salah satu isu strategis, tetapi dalam penilaian kinerja organisasi yang menjadi leading sektor pengelolan kawasan perbatasan negara secara praktis belum menjadi indikator perbatasan negara sebagai penilaian pencapaian kinerja organisasi.

Faktor lain yang menjadi penilaian adalah konsistensi kebijakan pengelolaan 
kawasan perbatasan adalah belum adanya payung hukum yang mengakomodir pencapaian kebijakan pengelolaan batas negera dan kawasan perbatasan. Kebijakan program kawasan perbatasan tidak secara spesifik dirinci tertuang dalam sistem perencanaan, baik dari visi misi, RPJP, RPJMD dan Rencana Strategis.

"Kalaupun ada kebijakan terkait pengelolaan kawasan perbatasan, program dan kegiatan yang dilakukan adalah mencari'celah' dari program yang bersinggungan dan menyangkut kawasan perbatasan. Program kawasan perbatasan tidak disebutkan secara spesifik dalam sistem perencanaan, kondisi seperti ini setidaknya akan berpengaruh pada pelaksanaan program/kegiatan terkait pembangunan kawasan perbatasan." (Wawancara dengan Kabag Perbatasan Prov. Kepri 12/11/2018).

Dari sisi birokrasi, baik struktur dan sumber daya yang ada cukup lemah untuk menjalankan fungsi pemberdayaan kebijakan pembangunan kawasan perbatasan. Kapasitas birokrasi dapat dilihat dari struktur dan SDM yang mendukung unit batas negara yang menjalankan tupoksi pengelolaan kawasan perbatasan masih sangat minim dan terbatas.

\section{Sumber Daya}

Sumber daya adalah suatu nilai potensi. George C. Edward III dalam Nugroho. Menyatakan sumber daya dalam hal ini dibedakan menjadi dua yaitu berupa sumber daya manusia (staff) dan non manusia (fasilitas atau sarana prasarana). Sumber daya manusia merupakan aset penting dalam suatu organisasi karena memiliki peran sebagai subyek pelaksana kebijakan dan sebagai pelaksana kegiatan. Operasionalisasi Sumber daya merupakan faktor penting demi terselenggaranya kebijakan dengan baik, dalam hal ini diperlukan sumber daya manusia (SDM) yang cukup serta di tingkatkan skill (kemampuan) yang di miliki oleh pelaksana kebijakan kawasan perbatasan.

Saat dilakukan wawancara,,nara sumber menyatakan bahwa persolaan sumber daya menjadi tantangan pada unit batas negara yang menjalankan tupoksi perbatasan.

"Saya ini Kabag Perbatasan campur campur, ada tiga unit yang dibawah bagian perbatasan disini. Pertama Urusan TU dan Keuangan, Kedua, urusan Batas Antar Daerah yang menangani perbatasan daerah di Kabupaten/Kota dan antar daerah dalam lingkup provinsi. Ketiga, Subbag Batas Negara yang memiliki tupoksi kawasan perbatasan negara." (Wawancara dengan Kabag Perbatasan Prov. Kepri 12/11/2018).

Dalam pelaksanaan tugas diungkapkan bahwa, unit batas negara minim mendapat dukungan sumber daya baik manusia dan lainnya. "Batas negara dapat dikatakan bekerja dengan dukungan sumber daya terbatas, baik dalam hal sumber daya manusia, fasilitas serta pendanaan sampai kegiatan pun tak banyak yang kita kerjakan. Awalnya unit batas negara ini sebuah badan, karena kebijakan daerah kemudian dilebur menjadi, subbag yang hanya 2 orang staf. Jadi kalo ada upaya membentuk kembali kelembagaan perbatasan kita dukung saja." (Wawancara dengan Kabag Perbatasan Prov. Kepri 12/11/2018).

Menurut Edward III, implementasi kebijakan dari aspek sumber daya meliputi:

\section{1) Sumber Daya Manusia (Staff)}

Persoalan sumber daya manusia, menjadi perhatian pada kelembagaan perbatasan di provinsi kepri. Informan Kassubag Batas Negara menyebut, terbatasnya sumber daya berpengaruh pada kinerja sehingga subbag batas negara belum mampu secara maksimal menghadirkan ataupun merumuskan kebijakan perbatasan. "Saya disini baru satu tahun, kitapun melaksanakan apa yang kita bisa. Kita juga tidak memaksakan diri, sebatas kemampuan saja yang kita laksanakan, termasuk soal anggaran. Banyakpun kegiatan, jika tidak maksimal dan tidak mampu untuk apa."(Wawancara dengan Kabag Perbatasan Prov. Kepri 12/11/2018) 
Disebutkan bahwa secara tupoksi bagian batas negara seharusnya memiliki kemampuan koordinasi yang baik dengan SKPD teknis baik di daerah bahkan dengan kementerian lembaga pada pemerintah pusat. Untuk pelaksanaan tugas tersebut perlu didukung sumber daya dan kelembagaan yang kuat.

Sebagaimana diketahui sumber daya manusia (staff) yang dimaksud adalah setiap perseorangan yang menjadi bagian dari struktur birokrasi yang secara langsung terlibat pada setiap kebijakan perbatasan. SDM yang memiliki kapasitas, akan dapat melaksanakan kesempatan menjalankan peran sebagai agen atau inisiasi utama dalam memberikan dorongan terkait kebijakan pengelolaan kawasan perbatasan.

Oleh karena itu, implementasi kebijakan pengelolaan kawasan perbatasan membutuhkan sumber daya yang cukup sehingga mampu melakukan apresiasi, mengagregasi, inisiasi, dan mengartikulasikan setiap isu kebijakan, sebab implementasi kebijakan tidak akan berhasil tanpa adanya dukungan dari sumber daya manusia yang cukup, baiksecara kualitas dan kuantitas. Kualitas sumber daya manusia berkaitan dengan keterampilan, dedikasi, profesionalitas, dan kompetensi di bidangnya, sedangkan kuantitas berkaitan dengan jumlah sumber daya manusia, karenanya sumber daya manusia akan berpengaruh terhadap keberhasilan implementasi, sebab tanpa sumber daya manusia yang handal implementasi kebijakan akan berjalan lambat.

2)Sumber Daya Non Manusia (fasilitas atau sarana prasarana)

Sumber daya non manusia adalah segala hal yang dapat membantu kelancaran pekerjaan, meliputi dana yang memadai, ketersedian sarana dan prasana pendukung kegiatan. Berdasarkan informasi melalui wawancara dengan Kabag, Kassubag dan Staf bagian batas negara, dinyatakan bahwa segala sesuatu terkait perumusan, termasuk koordinasi kebijakan pembangunan kawasan perbatasan belum dapat secara maksimal dilaksanakan. Pelaksanaan kegiatan selama ini masih bersifat rutinitas perkantoran dan koordinasi ringan terkait pelaksanaan kebijakan pengelolaan kawasan perbatasan.

Minimnya dukungan dana menjadi salah satu faktor penyebab keleluasaan unit batas negara untuk menyusun program dan kegiatan. "Koordinasi seperti pengumpulan data perencanaan dari OPD kita laksanakan, baik melalui forum rapat atau konsultasi, tapi memang kesannya seperti pengumpul data saja, usulan itu dapat dilaksanakan atau tidak, selama ini kita belum sampai kesana,"(Wawancara dengan Kabag Perbatasan Prov. Kepri 12/11/2018).

Sumber informan ketika wawancara menyebut, konsekuensi minimnya kegiatan yang dilakukan pada bagian batas negara, tidak banyak penggunaan sumber daya non manusia dalam mendukung pelaksanaan tugas. "Batas negara SDM-nya sedikit, anggaran dan kegiatan juga minim. Jadi memang belum banyak yang dapat kita kerjakan. Unit batas negara memiliki keterbatasan untuk menjalankan tupoksi sebagai imbas minimnya dukungan sumber daya manusia dan non manusia. Untukitu banyak halyang harus didorong utuk memfasilitasi bermacam agenda untuk menstimulasi pelaksanaan pembangunan kawasan perbatasan." (Wawancara dengan Kassubag Perbatasan Prov. Kepri 12/11/2018).

Edward III dalam teorinya menyebut bahwa sumber daya non manusia merupakan faktor penting dalam implementasi kebijakan. Implementor mungkin memiliki staf yang mencukupi, mengerti apa yang harus dilakukannya, dan memiliki wewenang untuk melaksanakan tugasnya, tetapi tanpa adanya fasilitas pendukung (sarana dan prasarana), maka implementasi kebijakan tersebut tidak akan berhasil. Fasilitas merupakan faktor yang sangat diperlukan dalam pelaksanaan suatu kebijakan.

\section{Disposisi}

Disposisi atau sikap dari pelaksana kebijakan adalah faktor yang penting dalam 
pendekatan mengenaipelaksanaan atau kebijakan publik. Jika pelaksanaan suatu kebijakan ingin efektif, maka para pelaksana kebijakan bukan saja harus mengetahui apa yang akan dilakukan tetapi harus memiliki kemampuan dalam menerjemahkan kebijakan yang dirumuskan dan diarahakan untuk dilaksanakan sehingga dalam praktiknya tidak terjadi bias dalam pelaksanaan kerja.

"Pemerintah sudah menetapkan Lokpri, tetapi pedoman dan tahapan yang dilaksanakan di lokpri itu kita belum ada. Katakan sebuah kecamatan sudah ditetapkan sebagai lokpri, tetapi sejak beberapa tahun ini indikator pembangunan atau pengembangan yang dilaksankan di kecamatan, sampai sekarang juga belum ada." (Wawancara dengan Kabag Perbatasan Prov. Kepri 12/11/2018)

Dinyatakan bahwa kebijakan perbatasan pada pelaksaan tugas memikul beban kerja yang dilematis. Perbatasan seolah memiliki jangkauan koordinasi yang luas dengan sejumlah kewenangan seperti adanya tupoksi mengkoordinaskan, tetapi tidak memiliki kekuatan untuk mendesakkan program, memiliki kewenangan mengevaluasi, tetapi kurang memiliki akses atas pekerjaan yang akan diawasi. Lembaga perbatasan ini diibaratkan Bappedanya kawasan perbatasan, Tetapi kewenangan dan koordinasi yang dimiliki Bappeda tidak ada pada bagian perbatasan.

Menurut Edward III dalam Winarno, disposisi adalah suatu keinginan, kemauan dan kecenderungan para pelaku kebijakan untuk melaksanakan serta mewujudkan kebijakan secara sungguh-sungguh. Proses disposisi merupakan faktor ketiga yang mempunyai konsenkuensi-konsenkuensi penting bagi implementasi kebijakan yang efektif.

Informan lain, Kassubag Keuangan dan Perencanaan Dinas Pekerjaan Umum dan Pertanahan Provinsi Kepri menyatakan sebagai instansi teknis pihaknya tidak memandang status perbatasanatautidak. "Kita menjalankan program karena program dibutuhkan masyarakat, sudah disusun, dan ada sumber dana," Menurutnya sebagai dinas yang menangani infrastruktur fisik, secara formal lembaganya selalu konsisten membangun infrastruktur sehingga dapat meningkatkan kebutuhan pembangunan dan aksesibilitas masyarakat." (Wawancara dengan Kassubag Perencanaan dan Keuangan Dinas PU Prov. Kepri 12/11/2018).

Kabag Perbatasan mengakui secara kelembagaan, bagian perbatasan belum maksimal menjalankan tugas secara ideal. "Kami belum memiliki data base kawasan, grand design yang menjadi rencana induk pengelolaan kawasan perbatasan daerah saja kami tidak punya. Karenanya secara kelembagaan kami belum dapat mendesakkan kebijakan kawasan perbatasan pada berbagai pihak dan kelompok kepentingan. Saat ini pekerjaan yang dilaksanakan masih berupa pengumpulan data dan koordinasi saja,"(Wawancara dengan Kabag Perbatasan Prov. Kepri 12/11/2018).

Dinyatakan, perlu analisa lebih lanjut bagaimana bagian perbatasan dalam melaksanakan tupoksi memiliki kewenangan yang bukan sekedar lembaga 'pengumpul' data tetapi memiliki penguatan kapasitas yang dapat dipatuhi dalam penyusunan kebijakan perbatasan oleh stake holder dan instansi terkait khususnya menuangkan kebijakan asimetris yang secara konsisten dilaksanakan pada kawasan perbatasan. Untuk pelaksanaan tugas sebagai aparat negara tidak bisa menghindar atas pekerjaan yang menjadi tanggung jawab. Apalagi sebagai ASN yang harus selalu siap mengapresiasi dan menampilkan attitude atas tugas dan tanggungjawab pada pelaksanaan tugas.

Kebijakan Pengelolaan Kawasan Perbatasan setidaknya semakin menguat dekade kebelakang. Menurut laporan Kemitraan Partnership Policy Paper No. 2/2011 sebuah jurnal yang mengkaji kemitraan bagi pembaruan tata pemerintahan (hal 5) menyebut salah satu hambatan yang dihadapi pemerintah dalam implementasi kebijakan pengelolaan kawasan 
perbatasan adalah belum sinkronnya pengelolaan kawasan perbatasan, baik menyangkut kelembagaan, program, maupun kejelasan wewenang.

Untuk itu perlu diisusun suatu desain besar pengelolaan kawasan perbatasan Indonesia yang dapat menjadi panduan kebijakan Pemerintah Pusat dan Pemerintah Daerah yang memiliki kawasan perbatasan. Dengan adanya suatu kebijakan pengelolaan yang komprehensif, maka diharapkan pembangunan kawasan perbatasan dapat dilakukan secara lebih terencana, terprogram, terarah, dan terukur. Kebijakan tentang desain besar ini diharapkan dapat dimasukkan dalam revisi peraturan perundang-undangan maupun peraturan daerah terkait pengelolaan kawasan perbatasan.

\section{Struktur Birokrasi}

Struktur birokrasi tercermin dalam Peraturan Gubernur No.Nomor 59 Tahun 2017 Tentang Kedudukan, Susunan Organisasi, Tugas Dan Fungsi, Serta Tata Kerja Perangkat Daerah dan dijalankan oleh subbag batas negara.

Kassubag batas negara menyatakan, banyak pihak yang menjadi bagian dari koordinasi pada pelaksanaan tugas perbatasan. Pelaksanaan koordinasi itu kita lakukan baik kepada instansi vertikal di pusat melalui kementerian dan lembaga khususnya dengan BNPP, serta instansi horizontal di daerah mulai dari desa, kecamatan dan kabupaten/kota dan antar SKPD provinsi.

"Pemerintah pusat menghendaki perbatasan didaerah punya lembaga perbatasan sendiri, nyatanya dana dekon tahun 2018 kita tidak diberi, salah satu pertimbanganya karena tidak ada lembaga perbatasan di daerah. Fungsi koordinasi kita luas, ego sektoral memang masih belum bisa dihindari. Belum lagi persoalan kewenangan yang masih terbatas," (Wawancara dengan Kassubag Batas Negara Prov. Kepri 12/11/2018).

Dikatakan bidang perbatasan saat ini merupakan penggabungan dari Badan Pengelola Perbatasan Tahun 2017. "Kapasitas kelembagaan yang ada saat ini jelas lebih kecil, bisa jadi kisaran 10 persen saja, pelaksanaan tugas jika dibandingkan dengan perbatasan yang dulu. Untuk melaksanaan tugas memang tidak banyak tupoksi yang bisa dijalankan," (Wawancara dengan Kabag Perbatasan Prov. Kepri 12/11/2018).

Atensi pemerintah terkait pengembangan/pengelolaan perbatasan dapat dinilai sebagai kebijakan baru. Mendasari teori Edward III, implementasi kebijakan perlu mempertimbangkan struktur birokrasi yang berkenaan dengan kesesuaian organisasi birokrasi yang menjadi penyelenggara implementasi kebijakan. Tantangannya adalah bagaimana agar tidak terjadi bureaucratic fragmentation karena struktur birokrasi menjadi penyebab proses implementasi menjadi jauh dari efektif. Sehingga terdapat aspek yang perlu di perhatikan pada struktur birokrasi dalam pelaksanaan kebijakan.

Aspek pertama adalah mekanisme dalam implementasi kebijakan biasanya sudah dibuat Standar Operational Prosedur (SOP). SOP menjadi pedoman bagi setiap implementator dalam bertindak agar dalam pelaksanaan kebijakan tidak melenceng dari tujuan dan sasaran kebijakan.

Narasumber saat dilakukan wawasancara menyebut banyak hal yang harus dipenuhi untuk mendukung pelaksanaan tugas perbatasan. "Sebelum SOP dipenuhi. sebaiknya disusun terlebih dahulu rencana induk pengelolaan kawasan perbatasan di Provinsi Kepri sehingga dapat menjadi pedoman arah kebijakan perbatasan yang secara bertahap akan dicapai. Mesti memiliki data base perbatasan, menyusun rencana induk, khususnya wilayah yang ditetapkan sebagai lokpri, untuk itu kita perlu grand design perbatasan," (Wawancara dengan Kabag Perbatasan Prov. Kepri 12/11/2018).

Aspek kedua adalah fragmentasi dimana terjadi penyebaran tanggungjawab kebijakan kepada beberapa badan/dinas yang berbeda sehingga memerlukan koordinasi. Fragmentasi menurut Edward III adalah pembagian tanggung 
jawab sebuah bidang kebijakan diantara unitunit.Tanggung jawab bagi suatu bidang kebijakan sering tersebar diantara beberapa organisasi. Konsenkuensi paling buruk dalam fragmentasi birokrasi adalah usaha terhambat koordinasi para birokrat karena alasan-alasan prioritas dari badan-badan yang berbeda mendorong birokrat untuk menghindari koordinasi dengan badanbadan lain.

Informan lainnya, yakni mantan sekretaris Badan Pengelola Perbatasan Provinsi Kepri 2011-2015, menilai kebijakan pengelolaaan perbatasan mesti di iringi kepastian kewenangan bukan sekedar koordinasi, tetapi bagaimana kebijakan dapat dilaksanakan.

"Namanya saja lembaga pengelola, apa yang dikelola mesti jelas. Kalo sekedar koordinasi, pelaksanaannya akan lemah, apalagi jika dalam koordinasi itu terdapat program/ kegiatan yang direkomendasikan. Tidak masalah tugas dilaksanakan oleh instansi lain, koordinasi. Setelah adanya lokpri. Mestinya kebijakan asimeteris itu dituangkan secara real termasuk adanya alokasianggaran, sehingga jelas tahapan dan progres pencapaian perbatasan, dalam hal ini kelembagaan perbatasan menguatkan koordinasi melalui perumusan kebijakan," (Wawancara dengan Kabag Pembangunan Pemdes/eks sekretaris Badan Pengelola Perbatasan Prov. Kepri 5/1/2019).

Lebih lanjut ditegaskan kebijakan perbatasan peran pemerintah pusat sangat mempengaruhi, sementara daerah dapat melakukan sinergi dengan menyiapkan dukungan kebijakan lain seperti penyertaan anggara atao lainya. "Kita ambil contoh adanya alokasi dana desa, atau kebijakan subsidi anggaran daerah tertinggal. Disitu pemerintah pusat yang mendorong dan jelas alokasi anggarannya. Pemerintah daerah bersinergi dan men-suport melalui dana pendamping atau kegiatan pendukung," (Wawancara dengan Kabag Pembangunan Pemdes/eks sekretaris Badan Pengelola Perbatasan Prov. Kepri 5/1/2019). Dalam sebuah penelitian (Desertasi)
Yudhi Wijayanto (2016:372), menyatakan, pembentukan lembaga-lembaga baru justru akan semakin membuat terjadi kesimpang-siuran peran, tugas, dan fungsi lembaga-lembaga baru tersebut. Pembentukan lembaga baru akan lebih tepat apabila lembaga bentukan tersebut diberikan kekuasaan yang otonom. Artinya lembaga tersebut diberi kewenangan untuk mengelola pulau-pulau terluar secara terpadu, sehingga diharapkan mampu menjalankan fungsi koordinasi, integrasi dan sinkronisasi.

\section{Faktor Pendukung}

Berlakunya undang-undang No. 43 Tahun 2008 tentang wilayah negara mengamanatkan adanya kebijakan pengelolaan kawasan perbatasan negara. Desentralisasi dan otonomi daerah menjadi penguat pemerintah Provinsi Kepulauan Riau untuk menggali potensi kawasan perbatasan negara untuk meningkatkan pembangunan dan kesejahteraan termasuk peluang memperkuat loby pada pemerintah pusat untuk mensinergikannya program/kegiatan pembangunan pusat dan daerah.

Melalui kebijakan desentralisasi asimetris dapat menjadi landasan hukum Pemerintah Provinsi Kepulauan Riau untuk melakukan negosiasi dan mendesak pemerintah pusat untuk mendistribusikan anggaran khusus kepada kawasan perbatasan negara khususnya wilayah yang sudah ditetapkan sebagai lokasi prioritas. apalagi kewajiban pembangunan kawasan perbatasan oleh pemerintah juga diamanatkan Undang-Undang Nomor 23 Tahun 2014 Tentang Pemerintahan Daerah khusunya Pasal 361 Ayat $(2,3,7)$ yang memberikan kewenangan dan kewajiban khusus bagi pemerintah pusat untuk membangun kawasan perbatasan negara agar tidak tertinggal dengan kemajuan kawasan perbatasan di negara tetangga.

Terkait kebijakan asimetris Veljanovski, 2010. Kebijakan asimetris dibagi dalam tiga level, yakni: asimetri politik; asimetri administratif; dan asimetri fiskal. Asimetri politik adalah bentuk desentralisasi asimetris yang umum terjadi di 
negara kesatuan namun mengatur perlakuan yang berbeda terhadap entitas masyarakat tertentu dengan alasan non ekonomis, seperti politik, historis, kebudayaan, dan lain-lain. Asimetri administratif diwujudkan dalam perbedaan kompetensi dan kapasitas Pemerintah Daerah dalam menjalankan urusannya, serta perbedaan bentuk interaksi antara Pemerintah Pusat dan Daerah. Sementara asimetri fiskal adalah level desentralisasi asimetris paling advanced karena sudah masuk pada dimensi pembiayaan pembangunan. Asimetri fiskal masuk pada ranah perbedaan perlakuan dalam wewenang penarikan pendapatan daerah dalam bentuk pajak dan non-pajak, serta belanja daerah dalam rangka pelaksanaan pembangunan.

Mengutif hasil kajian pengembangan kebijakan asimetris dalam pembangunan di kawasan perbatasan negara yang dilakukan oleh Bappenas melalui Direktorat daerah tertinggal transmingrasi dan perdesaan menyebut adanya beberapa rekomendasi kebutuhan intervensi pembangunan kawasan perbatasan di Kepulauan Riau meliputi:

1. Peningkatan infrastruktur fisik yang mendukung mobilitas dan kesejahteraan masyarakat kawasan perbatasan

2. Peningkatan sarana distribusi Perdagangan.

3. Pembangunan sarpras budidaya perikanan dan bantuan usaha perikanan.

4. Pembinaan usaha/industri pariwisata mikro dan kecil yang difasilitasi untuk meningkatkan nilai tambah termasuk penyelenggaraan event parawisata dan pengembangan desa wisata.

5. Pelatihan berbasis kompetensi, keterampilan, kewirausahaan dan keahlian.

6. Peningkatan pemagangan dalam negeri dan luar negeri serta perluasan kesempatan kerja.

\section{Faktor Penghambat}

Implementasi kebijakan mempunyai hambatan yang mempengaruhi pelaksanaan suatu kebijakan publik. Gow dan Morss dalam Pasolong (2011:59) mengungkapkan adanya hambatan dari dalam (faktor internal) dan dari luar (faktor eksternal) pada pelaksanaan kebijakan. Hambatan dari dalam atau yang sering disebut dengan faktor internal dapat dilihat dari ketersediaan dan kualitas input yang digunakan seperti sumber daya manusia, dana, struktur organisasi, informasi, sarana dan fasilitas yang dimiliki, serta aturan-aturan, sistem dan prosedur yang harus digunakan. Hambatan dari luar atau sering disebut sebagai faktor eksternal dapat dibedakan atas semua kekuatan yang berpengaruh langsung ataupun tidak langsung kepada proses implementasi kebijakan pemerintah, kelompok sasaran, kecenderungan ekonomi, politik, kondisi sosial budaya dan sebagainya.

Kepala bagian perbatasan Prov. Kepri mengakui belum terarahnya kebijakan perbatasan, hal ini terjadi karena belum adanya grand design bagaimana pengembangan atau pembangunan yang akan di laksanakan di kawasan lokpri. "Pemeritahah pusat sudah menetapkan 41 kecamatan di Kepri sebagai lokpri. Tetapi sampai saat ini kita tidak punya data base perbatasan. Pedoman arah kebijakan perbatasan pun kami tidak ada. Untuk mengarahkan lokpri yang ada, daerah mesti memiliki grand design.".

Persoalan lainnya adalah secara kelembagaan unit batas negara memiliki kapasitas yang terbatas, baik lembaga yang mengelola perbatasan itu sendiri maupun dukungan sumber daya manusia dan alokasi anggaran "Unit batas negara (sub bag batas negara) SDM-nya sedikit, anggaran dan kegiatan juga minim. Unit batas negara memiliki keterbatasan menjalankan tupoksi sebagai imbas minimnya dukungan sumber daya." (Wawancara dengan Kabag Perbatasan Prov. Kepri 12/11/2018).

\section{KESIMPULAN}

Kesimpulan dari penelitan ini berdasarkan teori implementasi Edward III meliputi 4 aspek 
yaitu:

\section{a. Komunikasi}

Pelaksanaan komunikasi yang sudah dilakukan meliputi rapat koordinasi (rakor/ raker), konsultasi atau melalui forum sosialisasi bersama pemerintah daerah dan pusat melalui BNPP selaku regulator tingkat nasional untuk mengkomunikasikan program kebijakan perbatasan negara termasuk bagaimana penerapannya didaerah.

b. Sumber Daya.

Aspek sumber daya meliputi sumber daya manusia dan sumber daya pendukung (fasilitas dan pendanaan). Pada aspek ini dukungan sumber daya manusia serta sumber daya pendukung seperti pendanaan dan dukungan kelembagaan pada sub bagian batas negara sangat minim. Kondisi ini terlihat dari minimnya program/ kegiatan yang telah dilakukan bagian batas negara dalam mendukung kinerja organisasi.

\section{c. Disposisi}

Aspek disposisi adalah bagaimana kebijakan pengelolaan perbatasan negara dapat menjadi pemahaman bersama yang dipatuhi semua pihak.

Sebagai kebijakan top down pelaksanaan kebijakan perbatasan di Kepri dari aspek disposisi dipengaruhi:

1. Kewenangan kelembagaan perbatasan yang masih lemah. Kewenangan koordinatif, dinilai belum mampu menampilkan lembaga yang memiliki kekuatan untuk mendesakkan program/kegiatan kawasan perbatasan pada lembaga teknis terkait.

2. Rapat koordinasi sebagai bentuk sosialisasi dan penyusunan program masih bersifat seremonial berupa pengumpulan data usulan pembangunan oleh kecamatan lokpri dan SKPD terkait, belum menampilkan arah pembanguna perbatasan yang dikehendaki.

3. Ego sektoral SKPD belum dapat dihindari, apalagi konsep pembangunan perbatasan yang belum terarah sehingga menjadi indikator utama pencapai pembangunan di Provinsi Kepri.

4. Untuk menguatkan prioritas pembangunan, pengelolaanataupunpengembangankawasan perbatasaan, indikator pembangunan perbatasan seharusnya tertuang dalam setiap dokumen perencanaan SKPD.

\section{d.Struktur Birokrasi}

Berdasarkan aspek struktur birokrasi, kapasitas subbag batas negara dinilai relatif kecil mengingat fungsi koordinasi yang harus dijalankan unit ini mulai dari level pusat seperti dengan BNPP maupun bersama pihak terkait didaerah. Dukungan struktur birokrasi juga terkait minimnya sumber daya manusia yang mendukung pelaksanaan tugas subbag batas negara.

Faktor pendukung implementasi kebijakan pegelolaan kawasan perbatasan dapat diidentifikasi adanya hal-hal yang dapat memberikan kesempatan dan peluang memacu percepatan kebijakan pengelolaan kawasan perbatasan di Kepulauan Riau, seperti adanya peraturan mulai dari undang-undang hingga peraturan daerah yang secara khusus menegaskan perlunya perhatian pada kawasan perbatasan.

Faktor penghambat implementasi kebijakan pengelolaan perbatasan adalah hal hal yang mempengaruhi pelaksanaan kebijakan kawasan perbatasan seperti minimnya dukungan sumber daya baik SDM dan alokasi anggaran dalam mendukung kebijakan pengelolaan kawasan perbatasan, fragmentasi kewenangan dan ego sektoral instansi masih menjadi kendala bagi unit batas negara pada bagian perbatasan dalam mengkoordinasikan program dan usulan pembangunan dikawasan perbatasan. Selain itu, sampai saat ini Provinsi Kepri belum memiliki grand design kawasan perbatasan.

Implikasi Teoritis, perlunya mengembangan penelitian kebijakan desentraliasi asimetris untuk mengetahui proses kebijakan pemerintah lainnya pada wilayah seperti kawasan perbatasan negara. 


\section{Saran}

Dalam mewujudkan upaya pengelolaan kawasan perbatasan negara di Kepri yang terkoordinasi, bersinergi beberapa hal yang perlu dilakukan;

1. Secara kelembagaan, perlunya reorientasi kewenangan kelembagaan perbatasan bukan sekedar lembaga koordinatif, tetapi sekaligus memiliki alokasi pendanaan yang dianggarkan oleh pemerintah pusat maupun daerah untuk mendukung terlaksananya rumusan program/kerja kebijakan perbatasan.

2. Perlunya orientasi misi pengeloaan perbatasan tidak sebatas isu strategis tetapi dituangkan secara nyata dalam Visi Misi kepala daerah, RPJP, RPJMD dan Rencana Strategis sehinga dapat diadopsi sebagai salah satu indikator pembangunan oleh setiap OPD dalam dokumen kerja mulai dari Renstra dan Renja untuk secara kongkrit berpartisipasi melaksanakan pembangunan di kawasan perbatasan.

3. Wilayah kecamatan yang sudah ditetapkan sebagai lokasi prioritas kawasan perbatasan, Pemerintah daerah dan pusat segera merumuskan kebutuhan perencanaan dan skala prioritas pembangunan yang akan dilaksanakan yang disertai alokasi anggaran.

4. Mengimplementasikan

kebijakan desentralisasi melalui pembangunan asimetris dalam pelaksanaan pembangunan di kawasan perbatasan.

5. Penguatan kelembagaan, SDM, dan dukungan dana yang cukup untuk mendukung perencanaan pembanguna dikawasan perbatasan.

6. Pemerintah daerah segera menyusun dan menetapkan rencana induk daerah/kawasan perbatasan sehingga menjadi pedoman arah kebijakan pembangunan kawasan perbatasan

\section{REFERENCE}

Agustino, Leo (2008). Dasar-Dasar Kebijakan Publik. Bandung: Alfabeta

Djohan, Djohermansyah, (2014) Merajut Otonomi Daerah Pada Era Reformasi, Jakarta: Penerbit IKAPTK.Dwiyanto, Agus, dkk. 2008. Reformasi Birokrasi Publik di Indonesia. Yogyakarta: UGM Press.

Edwards III, George, (1980) Implementing Public Policy. USA: Congressional Quarterly Press.

Hamdi, Muchlis dan Ismaryati, Siti, (2016) Metode Penelitian Administrasi. Tangerang Selatan: Universitas Terbuka.

Nugroho, Riant. (2017). Publik Policy. Jakarta: Elex Media Komputindo.

Nazir. Moch . (2011). Metode Penelitian. Jakarta: Ghalia Indonesia

Purwanto Erwan, Agus, Sulistyastuti Dyah, Ratih. (2012) Implementasi Kebijakan Publik, Konsep dan Aplikasinya di Indonesia. Jogjakarta: UGM.

Pasolong, Harbani, (2011) Teori Administrasi Publik. Bandung: Alfabeta

Prasojo, Eko dkk. (2016) Materi Pokok Pemerintahan Daerah. Tangerang Selatan: Universitas Terbuka.

Suwitri, Sri. Purnaweni, Hartuti. Krismartini. (2016) Materi Pokok Analisis Kebijakan Publik. Tangerang Selatan: Universitas Terbuka.

Winarno, Budi. (2005). Teori \& Proses Kebijakan Publik. Yogyakarta: Media Pressindo.

\section{A.Jurnal dan Karya Ilmiah}

Husnadi. (2006) Menuju Model Pengembangan Kawasan Perbatasan Daratan Antar Negara (Studi Kasus: Kecamatan Paloh dan Sajingan Besar Kabupaten Sambas, Kalimantan Barat) Tesis Undip Semarang.

Kasim, Azhari. makalah public policy (2018). Materi Inisiasi pembelajaran Analisis Kebijakan Publik. Universitas Terbuka. 
Wijayanto, Yudhi(2016). Implementasi Kebijakan Pemerintah Terhadap Pengelolaan PulauPulau Kecil Terluar (Studi Kasus Pulau Miangas Kabupaten Talaud Provinsi Sulawesi Utara) Desertasi FISIP UI.

Said, M Mas'ud, Makalah Desentralisasi Asimetris. Jurnal Kemitraan Partnership Policy Paper EdisinNo. 2/2011

Rencana Induk Badan Nasional Pengelola Perbatasan tahun 2011 - 2014 .

BPS Kepulauan Riau, (2013). Penurunan Jumlah Penduduk Miskin Cenderung Hanya Terjadi di Daerah Perkotaan.

Veljanovski, A. M. 2010. "The Model of Asymmetric Fiscal Decentralization in

The Theory and The Case of Republic of Macedonia”. IustinianusPrimus Law Review, Vol. 1:1. Dalam Laporan Akhir Kajian Pengembangan Kebijakan Asimetris dalam Pembangunan di Kawasan Perbatasan Negara, Direktorat Daerah Tertinggal, Transmigrasi dan Perdesaan Kementerian PPN/Bappenas 2016.

\section{B. Peraturan Perundang-undangan}

Undang-undang Nomor 43 Tahun 2008 tentang Wilayah Negara.

Undang-undang Nomor 23 Tahun 2014 tentang Pemerintah Daerah.

Peraturan Presiden Nomor 78 Tahun 2005 tentang Pengelolaan Pulau Pulau Kecil Terluar.

Peraturan Pemerintah Republik Indonesia Nomor 26 Tahun 2008 tentang Rencana Tata Ruang Nasional.

Keputusan Presiden Nomor 6 Tahun 2017 tentang Penetapan Pulau-Pulau Kecil Terluar.

Peraturan Menteri Dalam Negeri Republik Indonesia Nomor 140 Tahun 2017 tentang Pembentukan Badan Pengelola Perbatasan Di Daerah.

Peraturan Daerah Provinsi Kepulauan Riau Nomor 1 Tahun 2018 tentang Perubahan atas Peraturan Daerah No.8 Tahun 2016 tentang Rencana Pembangunan Jangka Menengah Daerah Tahun 2016-2021.

Peraturan Gubernur Kepulauan Riau Nomor 59 Tahun 2017 Tentang Kedudukan, Susunan Organisasi, Tugas Dan Fungsi, Serta Tata Kerja Perangkat Daerah.

\section{C.Media dan portal berita}

h t t p s : / / n a s i o n a l. k o m pas . com / $\mathrm{read} / 2014 / 11 / 25 / 12000021 /$ Tantangan. Birokrasi.Pemerintahan.Jokowi-JK Eko Prasojo 